\title{
DETERMINATION OF CLAD PLATES RESIDUAL STRESSES BY X-RAY DIFFRACTION METHOD
}

\author{
Branko Mateša, Zoran Kožuh, Marko Dunđer, Ivan Samardžić
}

Original scientific paper The paper elaborates the influence that clad procedure has on the level and nature of residual stresses in clad plates. There are three clad procedures applied, as follows: hot rolling, submerged arc welding (SAW) with strip electrode in two layers and explosion welding. Theoretical basics on residual stresses measured by x-ray diffraction are reviewed in the paper, with special emphasis put on problems of underclad cracking tendency. In all applied cladding procedures, usage of heat treatment by anealing resulted in the decrease of residual stresses values. However, transformation of commpresed stresses into tensile stresses in some cases was very unfavourable, if referring to the tendency of plating corrosion resistant steel to stress corrosion and to underclad cracking.

Keywords: clad plates; residual stresses; $x$-ray diffraction method; underclad cracking

Utvrđivanje zaostalih naprezanja platiranih ploča metodom difrakcije x-zraka

Izvorni znanstveni članak Istraživan je utjecaj postupka platiranja na veličinu i narav zaostalih naprezanja platiranih limova. Rabljena su tri postupka platiranja: toplo valjanje, elektrolučno navarivanje pod praškom (EPP) s elektrodnim trakama u dva sloja, te platiranje eksplozijom. Izložen je prikaz teorijskih osnova mjerenja naprezanja difrakcijom x-zraka s posebnim naglaskom na problem sklonosti pukotinama ispod navara. Kod svih primijenjenih postupaka platiranja, uporaba toplinske obradbe žarenjem dovela je do pada vrijednosti zaostalih naprezanja. No pretvorba tlačnih naprezanja u vlačna kod nekih slučajeva je vrlo nepovoljna sa stajališta sklonosti korozijski postojanog platirajućeg čelika napetosnoj koroziji kao i pukotinama pod navarom.

Ključne riječi: metoda difrakcije x-zraka; platirane ploče; pukotine pod navarom; zaostala naprezanja

\section{Introduction}

Residual stresses occur during welding due to inhomogeneous temperature distribution. At the bonding interface, temperatures are significantly higher than in the base materials [1]. It is also related to explosion welding process, due to partial conversion of elevated impact energy to heat, which may produce local melting or annealing close to the interface. During cooling, the regions near the cladded interface tend to contract while impeded by the surrounding base material. This may lead to elevated tensile stresses close to the welding interface with balancing compressive stresses throughout the base metal [1]. The performance of cladded plates can be influenced by residual stresses formed during welding or post weld heat treatment (PWHT), which may cause dimensional instability during cutting or machining operations, as well as underclad cracking. In the case of dissimilar materials, residual stresses are increased by differences in elastic properties (separate module elasticity $\mathrm{E}$ and thermal expansion coefficient of the materials $\alpha$ ). It is important to determine size and nature of residual stresses at plated construction with dissimilar steels. Knowledge about tensile residual stresses is essential because there is a possibility of cracking tendency of corrosion resistant steel to stress corrosion. Knowledge about compressive residual stresses and their influence on construction stability is also indispensable [2].

Underclad cracks are intergranular separations placed in the coarse-grained heat-affected zone of low-alloy steels below the weld-cladding overlay, whose dimensions are no less than about $3 \mathrm{~mm}$ deep and $3 \mathrm{~mm}$ long [3]. Weld-overlay cladding with high-heat-input processes provides the susceptible microstructure and tensile residual-stress separately at weld passes overlapping. Postweld heat treatment provides the critical temperature region, usually between 600 and $650{ }^{\circ} \mathrm{C}$, i.e. with low creep ductility [3]. When depositing the first layer, a coarse-grained microstructure is generated in the HAZ. While depositing the second layer, the second fusion line is situated at the surface of the first layer. The coarse-grained zone microstructure is refined. In case of the incomplete refinesment, final product still contains areas with coarse-grained microstructure. When PWHT is applied, coarse-grained areas have tendency to potential intergranular underclad crack locations [4].

\section{Materials and experiment plan}

The experiment objective is to determine the influence of cladding procedure on the nature and values of residual stresses in plating stainless steel surfaces. The experiment plan of measuring residual stresses by x-ray diffraction is presented in Tab. 1. Dimensions of examined plates were $100 \times 100 \times \delta \mathrm{mm}$. The base material ASTM A387 Gr.12 is delivered in normalised and the plating ASTM A240 TP304L in quenched state (Tab. 2).

Table 1 Plan of experiments referring to residual stresses measurement

\begin{tabular}{|l|c|c|}
\hline \multicolumn{1}{|c|}{$\begin{array}{c}\text { Residual stresses by x-ray } \\
\text { diffraction measurement }\end{array}$} & $\begin{array}{c}\text { No heat } \\
\text { treatment } \\
\text { B1 }\end{array}$ & $\begin{array}{c}\text { Heat } \\
\text { treatment } \\
\text { B2 }\end{array}$ \\
\hline Sample plated by hot rolling A1 & A1B1 & A1B2 \\
\hline $\begin{array}{l}\text { Sample plated by SAW with stripped } \\
\text { electrodes A2 }\end{array}$ & A2B1 & A2B2 \\
\hline $\begin{array}{l}\text { Sample plated by explosion welding } \\
\text { A3 }\end{array}$ & A3B1 & A3B2 \\
\hline
\end{tabular}

Overlaying is performed in two beads using a device to prevent plate distortion. Afterwards, clad plate is 
examined by dye-penetrant testing with intention to dicover surface errors. Ultrasound method tandemtechnique with $70^{\circ}$-angle probes frequency $2 \mathrm{MHz}$ is used with intention to discover under-cladding cracks caused by heat-affected zone (HAZ) reheating (Tab. 3).

Table 2 Chemical and mechanical properties of the base materials

\begin{tabular}{|c|c|c|c|}
\hline \multicolumn{2}{|c|}{$\begin{array}{l}\text { Base and cladding } \\
\text { materials }\end{array}$} & $\begin{array}{l}\text { ASTM A } \\
387 \text { Gr.12 }\end{array}$ & $\begin{array}{c}\text { ASTM A } \\
240 \text { TP304L }\end{array}$ \\
\hline \multirow{8}{*}{ 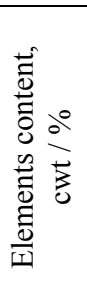 } & $\mathrm{C}$ & 0,13 & 0,026 \\
\hline & $\mathrm{Si}$ & 0,28 & 0,48 \\
\hline & $\mathrm{Mn}$ & 0,78 & 1,33 \\
\hline & $\mathrm{P}$ & 0,008 & 0,030 \\
\hline & $\mathrm{S}$ & 0,10 & 0,030 \\
\hline & $\mathrm{Cr}$ & 1,07 & 18,7 \\
\hline & Mo & 0,52 & - \\
\hline & $\mathrm{Ni}$ & - & 10,8 \\
\hline \multicolumn{2}{|c|}{ Yield strength $\mathrm{Re} / \mathrm{MPa}$} & 421 & 218 \\
\hline \multicolumn{2}{|c|}{ Tensile strength $\mathrm{Rm} / \mathrm{MPa}$} & 598 & 591 \\
\hline \multicolumn{2}{|c|}{ Elongation $\delta_{5} / \%$} & 26 & 63 \\
\hline \multicolumn{2}{|c|}{ Charpy impact energy / J } & 169 & 210 \\
\hline
\end{tabular}

Table 3 Parameters and characteristics of submerged arc overlaying with strip electrodes

\begin{tabular}{|c|c|}
\hline \multicolumn{2}{|c|}{$\begin{array}{l}\text { Parameters and characteristics of submerged arc welding } \\
\text { (SAW) overlaying-surfacing }\end{array}$} \\
\hline $\begin{array}{l}\text { Electrode strip and flux } \\
(1 . \text { bead, dim. } 60 \times 0,5 \mathrm{~mm}) \\
\text { AWS E 309L } \\
\text { Creq. } / \text { Nieq }=1,77\end{array}$ & $\begin{array}{l}\text { UTP 6824LC; } \\
\text { UP Flux6824 }\end{array}$ \\
\hline $\begin{array}{l}\text { Electrode strip and flux } \\
(2 . \text { bead, dim. } 60 \times 0,5 \mathrm{~mm}) \\
\text { AWS E } 308 \mathrm{~L} \\
\text { Creq./Nieq }=1,69\end{array}$ & $\begin{array}{l}\text { UTP 6824LC; } \\
\text { UP Flux } 6820\end{array}$ \\
\hline $\begin{array}{l}\text { Equipment for SAW } \\
\text { overlaying }\end{array}$ & LINCOLN WELD-NA-3S \\
\hline $\begin{array}{l}\text { Overlaying current strength / } \\
\text { A }\end{array}$ & $580 \ldots 600$ \\
\hline Overlaying current tension / V & $29 \ldots 30$ \\
\hline Overlaying velocity $/ \mathrm{cm} / \mathrm{min}$ & $\cong 20$ \\
\hline $\begin{array}{l}\text { Base material preheating } \\
\text { temperature } \vartheta_{\mathrm{p}} /{ }^{\circ} \mathrm{C}\end{array}$ & $\cong 150$ \\
\hline Interlayer temperature $\vartheta_{\mathrm{m}} /{ }^{\circ} \mathrm{C}$ & $\cong \vartheta_{\mathrm{p}} /{ }^{\circ} \mathrm{C}$ \\
\hline Preheating mode & Gas fire (propane-butane) \\
\hline $\begin{array}{l}\text { Temperature controls } \\
\text { equipment }\end{array}$ & $\begin{array}{l}\text { Thermo-crayons; } \\
\text { contact pyrometers }\end{array}$ \\
\hline Beads overlapping / mm & $3 \ldots 4$ \\
\hline Total overlay elevation / mm & $6 \ldots 7$ \\
\hline
\end{tabular}

Explosion cladded joint is produced by using a single cladding shot and parallel joining scheme. Distance between flayer and fixed plate was $10 \mathrm{~mm}$ with $20 \mathrm{~mm}$ thick explosive powder layer. Explosive material ammonite (85\% ammonium nitrates as oxidizer $+12 \%$ explosive trinitrotoluene (TNT) $+3 \% \mathrm{Al}$ as fuel) in powder form is used with a standard commercial blasting cap no. 8 instantaneous as activator to detonate the explosive. Bond integrity is verified by using straightbeam ultrasonic inspection procedures. Specifications provided several acceptance criteria depending on customer's needs, the more stringent being $25 \mathrm{~mm}$ maximum length of any indication and $99 \%$ minimum sound bond area.

\section{The basic theory of residual stresses measurment by x-ray diffraction}

This stress analysis technique is based on deformation crystals lattice measurement $\Delta d / d$ (Fig. 1).

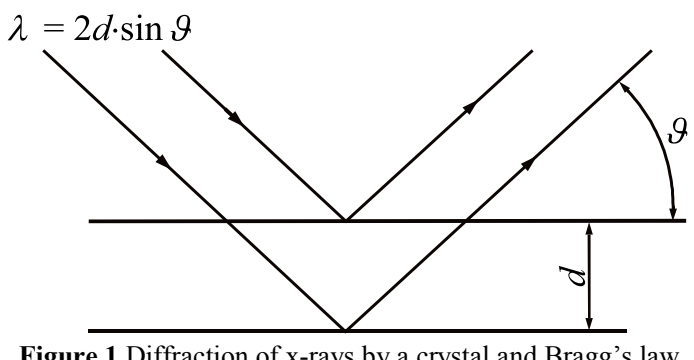

Figure 1 Diffraction of x-rays by a crystal and Bragg's law

The $\mathrm{x}$-rays of appropriate wavelength are used for measurements. Interference lines $(\mathrm{h}, \mathrm{k}, \mathrm{l})$ are suported by special devices (camera photograph for reflected $\mathrm{x}$-rays filming or diffractometer-goniometer with proportional and scintillation counter). At computing, elastomechanics equations are used. If residual stresses are of range size 10 $\mathrm{Pa}$, distance between crystal lattice planes changes in relation to status without residual stresses for only a tenth of a thousandth part. Because of the stated, and if referring to guarantee satisfied sensitivity methods, diffractometers measuring at greater Braggs angles $2 \vartheta$ (near $180^{\circ}$ ) should be performed $[5,6]$. According to the Bragg's law, it follows:

$\lambda=2 d \cdot \sin \vartheta$

where: $\lambda$-x-ray wavelength, $d$-distance between nearby crystal lattice planes, $\vartheta$ - angle between primary/reflected $\mathrm{x}$-ray beam and crystal lattice planes.

Using the differentials Eq. (1) at $\lambda=$ const. it follows:

$\varepsilon=\frac{\Delta d}{d}=-\frac{1}{2} \cdot \operatorname{ctan} \vartheta \cdot d(2 \vartheta)$

or

$\frac{\Delta d}{d}=-\operatorname{ctan} \vartheta \cdot \Delta \vartheta$

It confirms the fact that the crystal lattice planes distances change, causing doubled angle $\vartheta$ (Bragg's angle) to change. The $\mathrm{x}$-ray diffraction measurement is technically limited to $5 \div 30 \mu \mathrm{m}$ thick surfacing layer. If it is assumed that the stress in surfacing layer thickness direction is zero (0), there exist only main stresses on surface layer.

Related to activity direction, the mentioned stresses $\sigma_{1}$ and $\sigma_{2}$ are in reciprocally perpendicular position. According to the above assumption, the relations between main stresses and deformation on the sample surfaces using Hooke's law are as follows:

$\varepsilon_{1} E=\sigma_{1}+v \sigma_{2}$
$\varepsilon_{2} E=\sigma_{2}+v \sigma_{1}$
$\varepsilon_{3} E=-v\left(\sigma_{1}+\sigma_{2}\right)$ 
where: $E$ - elasticity modulus, $v$ - Poisson's coefficient and $\varepsilon$-measured material sample deformation.

Furthermore, relations between stresses tensors and deformation tensors are defined by the following equation with parameters presented in Fig. 2.

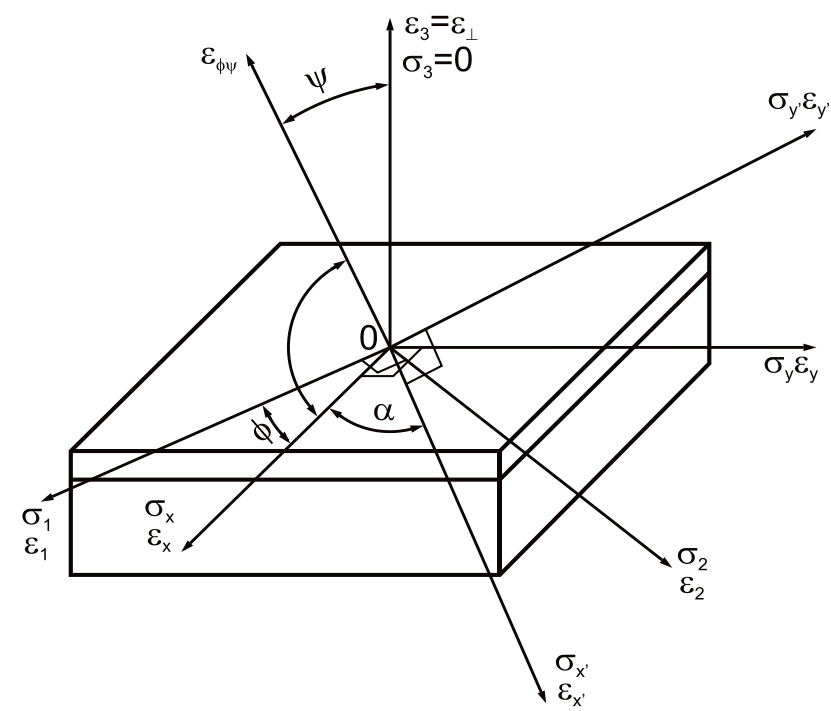

Figure 2 Coordinate system at deformation determination and residual stresses on sample surface by $\mathrm{x}$-ray diffraction technique [7]

$\varepsilon_{x} E=\sigma_{x}-v \sigma_{y}$
$\varepsilon_{y} E=\sigma_{y}-v \sigma_{x}$
$\varepsilon_{3} E=\varepsilon_{\perp} E=-v\left(\sigma_{x}+\sigma_{y}\right)=-v\left(\sigma_{x}+\sigma_{y}\right)$

In direction determined by azimuth angle $\phi$, and polar angle $\psi$, there is:

$$
\begin{aligned}
& \varepsilon_{\phi, \psi}=\sin ^{2} \psi\left(\varepsilon_{1} \cdot \cos ^{2} \phi+\varepsilon_{2} \cdot \sin ^{2} \phi\right)+\varepsilon_{\perp}-\varepsilon_{\perp} \cdot \sin ^{2} \psi \\
& \text { and } \varepsilon_{x}=\varepsilon_{1} \cdot \cos ^{2} \phi+\varepsilon_{2} \sin ^{2} \phi
\end{aligned}
$$

as well as:

$$
\begin{aligned}
& \varepsilon_{\phi, \psi}-\varepsilon_{\perp}=\left(\varepsilon_{x}-\varepsilon_{\perp}\right) \cdot \sin ^{2} \psi \\
& \left(\varepsilon_{\phi, \psi}-\varepsilon_{\perp}\right) E=(1+v) \cdot \sigma_{x} \cdot \sin ^{2} \psi
\end{aligned}
$$

At determination $\sigma_{x}$ two measurements of deformation change should be realized.

If: $d_{0}-$ distance between crystal lattice planes at unstrained status; $d_{\perp}-$ distance between crystal lattice planes parallel with sample surface at strained status, and $d_{\phi, \psi}$ - distance between crystal lattice planes that is normal to direction $(\phi, \psi)$ at strained status.

Deformation record as:

$$
\varepsilon_{\perp}=\frac{\left(d_{\perp}-d_{0}\right)}{d_{0}} ; \quad \varepsilon_{\phi, \psi}=\frac{\left(d_{\phi, \psi}-d_{0}\right)}{d_{0}}
$$

followed by: $\varepsilon_{\perp}-\varepsilon_{\phi, \psi}=\frac{\left(d_{\perp}-d_{\phi, \psi}\right)}{d_{0}}$

Due to the small changes of distance between crystal lattice planes caused by residual stresses, the following is roughly drawn:

$$
\begin{aligned}
& {\left[\frac{(1+v)}{E}\right] \cdot \sigma_{x} \sin ^{2} \psi=\varepsilon_{\phi, \psi}-\varepsilon_{\perp} \approx} \\
& \approx \frac{\left(d_{\phi, \psi}-d_{\perp}\right)}{d_{0}}=+\frac{\Delta d}{d}=-\operatorname{ctan} \vartheta \Delta \vartheta_{1}
\end{aligned}
$$

Since $E$ and $v$ material properties are from Eq. (11) $\sigma_{x}$ residual stresses can be determined.

At determined reflection type Bragg's angles difference $\Delta \vartheta_{1}$ should be measured.

First, the vertical line on sample surface coincides with the axis of symmetry between primary and reflected $\mathrm{x}$-ray beam. Then the measuring between normal line on sample surface and axis of symmetry is $\psi$ angle. Measurement procedure is like that at determination $\sigma_{x}$, but the sample should be rotated round its normal at $90^{\circ}$ $[8,9]$.

Residual stress $\sigma_{y}$ is determined from equation:

$$
\left[\frac{(1+v)}{E}\right] \cdot \sigma_{y} \sin ^{2} \psi=\varepsilon_{\phi+\frac{\pi}{2} ; \psi}-\varepsilon_{\perp}=-\operatorname{ctan} \vartheta \Delta \vartheta_{2}
$$

\subsection{Description of diffractometer operation}

Diffractometer is a special device used for measuring of all Bragg's angles x-rays reflection on crystals, with respect to precise position and intensity of DebyeScherrer lines. Equipment is composed of three parts: $\mathrm{x}$ ray source, goniometer and detector (Fig. 3). During the measuring process the angle is changed, i.e. vertical line on the sample surface and axis of symmetry between primary and reflected beams is close to $\psi$ angle (Fig. 4).

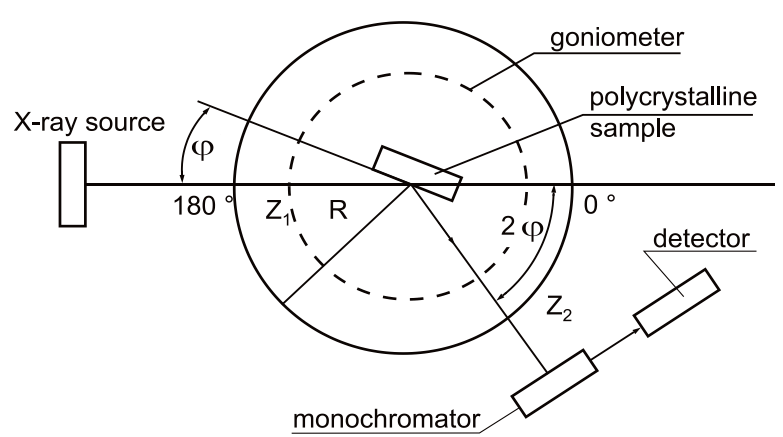

Figure 3 Diffractometer working principle [9]

At flat samples, allready for $\psi=0$ primmary $\mathrm{x}$-ray beams divergency causes unsymmetrical lines to expand and to move (Fig. 5). For primmary beam angle $2 \delta<1$, at measured sttresses, error is less than $10 \mathrm{MPa}$, which is technically acceptable. Divergence of primary $x$-ray beam could be eliminated by detectoric slits (Z1 and Z2) or by other technical solution.

Detector moves on gonimetric circle $\mathrm{M}$ and registers reflected $\mathrm{x}$-ray beam intensity. The focusing condition is that $\mathrm{X}$-ray source, surface plane of sample $U$ and primmary slits A are situated on circle $\mathrm{K}$ (Figs. $3 \div 5$ ).

This focused circle during focusing permanently changes its diameter. In this way, the focus place from point A moves to point A', which is expanding lines on detectors. One solution is that detector slits shoud be moved to the distance AA' (Fig. 4), but such correction is 
rarely used as a procedure, so the defocusing effects will be eliminated in other ways.

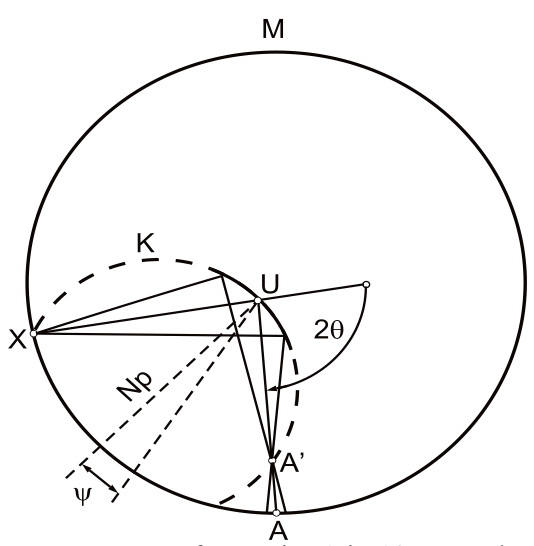

Figure 4 Focus movement from point $A$ in $A^{\prime}$ at sample rotation for angle $\psi[7,8]$

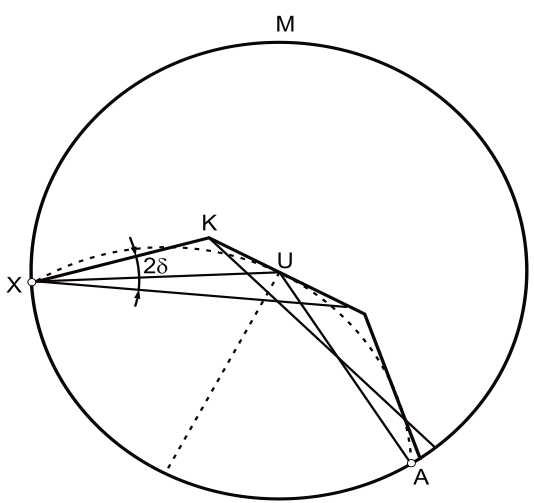

Figure 5 Defocusing effect at flat samples measuring [7, 8]

Interference lines for different Bragg's angles $\vartheta$ and different $\psi$ angles in reflection area are recorded as well as interference lines position. At $\psi$ diffractometer, compared to $\Omega$ - diffractometer, which has common $\vartheta$ and $\psi$ - axis, these axes are reciprocally perpendicular (Fig. 6).

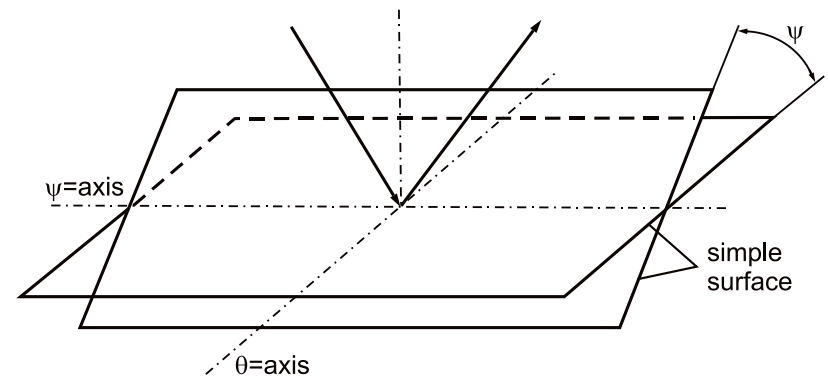

Figure $6 \theta$-and $\psi$-axes position at $\psi$-diffractometer [10]

In this way, sample rotation achieves higher efficiency of $\psi$-area. At $\psi$-diffractometers, goniometric circle magnification, in comparison with $\Omega$ diffractometer, results in higher measurement precision.

\subsection{Measurements specification and their characteristics}

From cladded plates dimensions $100 \times 100 \times \delta$, tested samples with dimensions $20 \times 30 \mathrm{~mm}$ are cut by mechanical procedure. This dimension was acceptable for special constructed sample holder.
Since the penetrating power of x-rays used for diffraction is small, the surface preparation is very important, since it should be smooth. This is achieved by surface grinding followed by mechanical polishing. The main limitation of that method is that it can be used only for the evaluation of surface residual stresses. If stress distribution through the thickness is required, surface layers have to be removed by electropolishing $[8,10]$.

Measurements are performed using Siemens Kristaloflex-4 x-ray diffraction system equiped with $\mathrm{Cu}$ radiation source, $\lambda \mathrm{Cu} K_{\alpha}=1,5405 \AA$. Such device operates on $\psi$-principle (Fig. 7).

Measurement of residual stresses is on interference lines movement at family of planes (311) based on surface centric crystal latice of $\gamma$-phase. At measurements, angle $\psi$ between a normal on sample surface and symmetry axis between primary and reflected $\mathrm{x}$-rays is changed in area $0^{\circ} \div 50^{\circ}$.

As the angle $2 \vartheta$ should be as large as possible, with intention to obtain sufficient accuracy, aproximatelly $140^{\circ}$ angle is for interference (311).

As mentioned, horizontal goniometer with $\mathrm{Cu}$-anode is used for residual stresses analysis with the following parameters:

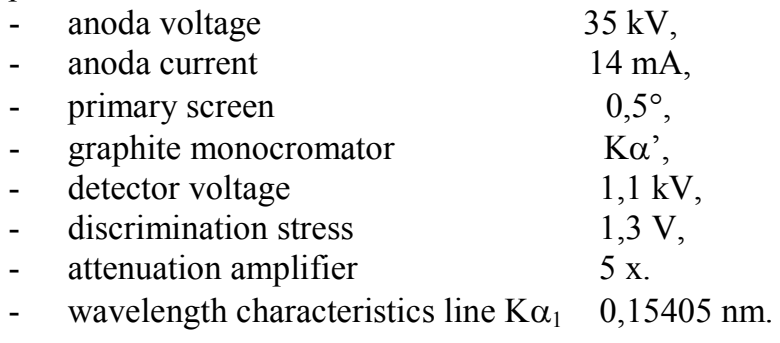

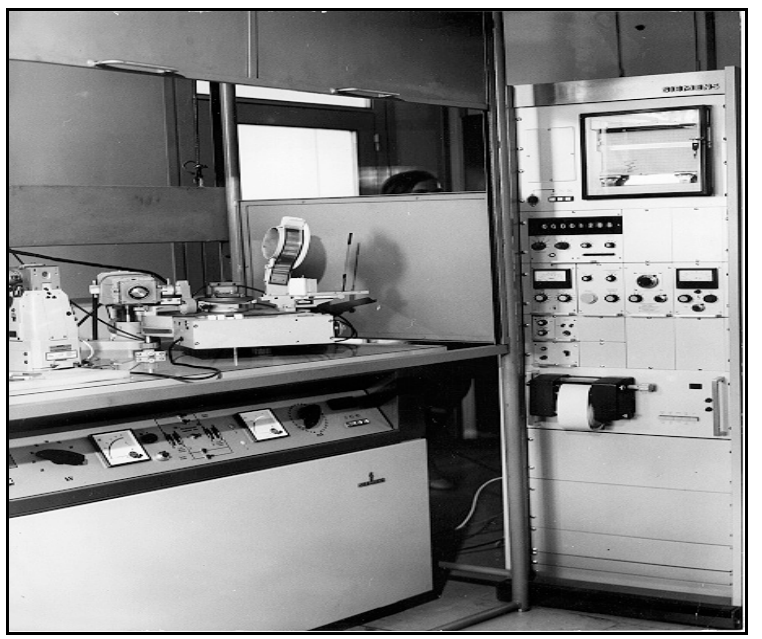

Figure 7 Photographic presentation of $\psi$-principle diffractometer Siemens Kristaloflex - 4

\section{Measuring results and their analysis}

Since the interference line (311) is extended, determination of maximum line position is relatively serious. Due to precision, maximum intensity lines are aproximated by polynomial equation (Tab. 4): $y=a x^{2}+b x+c$, where the function top is: $x=-b / 2 a$.

Therefore, electronic impulse counter determines the position of interference lines maximum. The angle $(2 \vartheta)$ firstly increased with step of $0,02^{\circ}$ (at first three examined samples) and subsquently of $0,05^{\circ}$ (at other three 
examined samples). Firstly, measurement is performed on samples cladded by strip electrodes SAW.

Table 4 Review of approximations function coefficients for $y=a x^{2}+b x$

\begin{tabular}{|c|c|c|c|c|c|}
\hline Sample & $\psi / \circ$ & $\phi 1^{\circ}$ & $a$ & $b$ & $c$ \\
\hline \multirow{4}{*}{ A1.B1 } & 0 & 0 & $-0,0237$ & 0,4590 & 432,2339 \\
\hline & 0 & 90 & $-0,0270$ & 0,6261 & 466,8482 \\
\hline & 50 & 0 & $-0,0066$ & 0,9838 & 200,6824 \\
\hline & 50 & 90 & $-0,0057$ & 0,8922 & 166,9217 \\
\hline \multirow{4}{*}{ A1.B2 } & 0 & 0 & $-0,0448$ & 0,1494 & 718,6231 \\
\hline & 0 & 90 & $-0,0275$ & 0,3577 & 481,6651 \\
\hline & 50 & 0 & $-0,0202$ & 2,7598 & 397,8683 \\
\hline & 50 & 90 & $-0,0059$ & 0,8199 & 180,1092 \\
\hline \multirow{4}{*}{ A2.B1 } & 0 & 0 & $-0,0108$ & 0,6517 & 451,6305 \\
\hline & 0 & 90 & $-0,0072$ & 0,3160 & 372,1962 \\
\hline & 50 & 0 & $-0,0144$ & 0,9451 & 425,1561 \\
\hline & 50 & 90 & $-0,0201$ & 0,6328 & 571,0278 \\
\hline \multirow{4}{*}{ A2.B2 } & 0 & 0 & $-0,01164$ & 0,7963 & 561,2672 \\
\hline & 0 & 90 & $-0,01494$ & 0,8805 & 598,1514 \\
\hline & 50 & 0 & $-0,00827$ & 0,5252 & 394,5661 \\
\hline & 50 & 90 & $-0,01298$ & 0,0874 & 424,5698 \\
\hline \multirow{4}{*}{ A3.B1 } & 0 & 0 & $-0,0172$ & $-0,5873$ & 534,516 \\
\hline & 0 & 90 & $-0,0180$ & 0,1717 & 521,1609 \\
\hline & 50 & 0 & $-0,0090$ & 0,7880 & 245,5775 \\
\hline & 50 & 90 & $-0,0076$ & 0,8498 & 212,8923 \\
\hline \multirow{4}{*}{ A3.B2 } & 0 & 0 & $-0,0338$ & $-1,3148$ & 627,6186 \\
\hline & 0 & 90 & $-0,0177$ & 0,2305 & 390,9063 \\
\hline & 50 & 0 & $-0,0101$ & 0,7815 & 251,7684 \\
\hline & 50 & 90 & $-0,0097$ & 0,5016 & 207,0242 \\
\hline
\end{tabular}

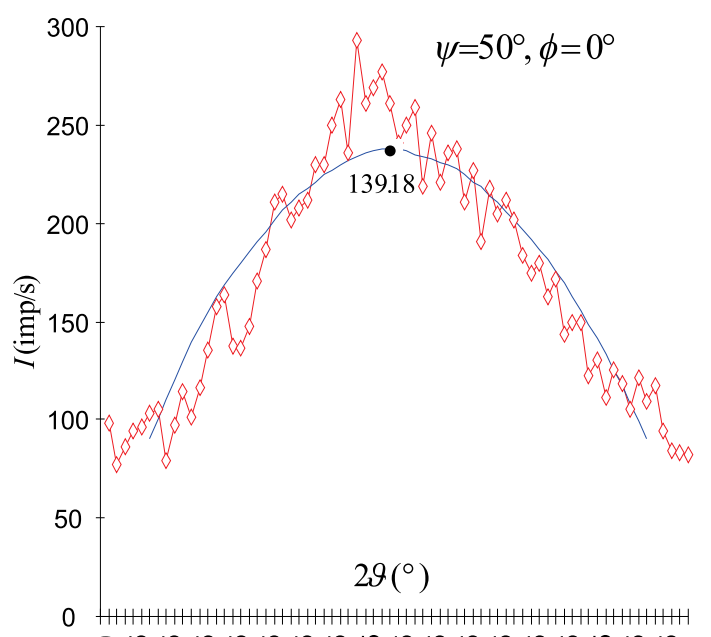

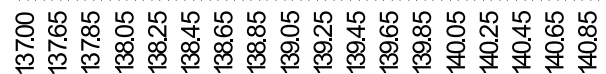

Figure 8 Graphical presentation of maximum intensity lines for no-heat-treated sample cladded by hot rolling

Fig. 8 graphically presents maximum intensity lines for sample plated by hot rolling, derived from impulses data counted out and approximation function with maximum at $139,18^{\circ}$ for $\psi=50^{\circ}$ and $\phi=0^{\circ}$.

Afterwards, cladded samples are submitted to the $\mathrm{x}$ ray diffraction measurements by explosion welding, as well as by hot rolling. In the interval of $2^{\circ}$ peak area of interference line, the quadratic parabole is used as approximation.

Table 5 Review of measured characteristics and x- ray diffraction measurements on residual stresses values

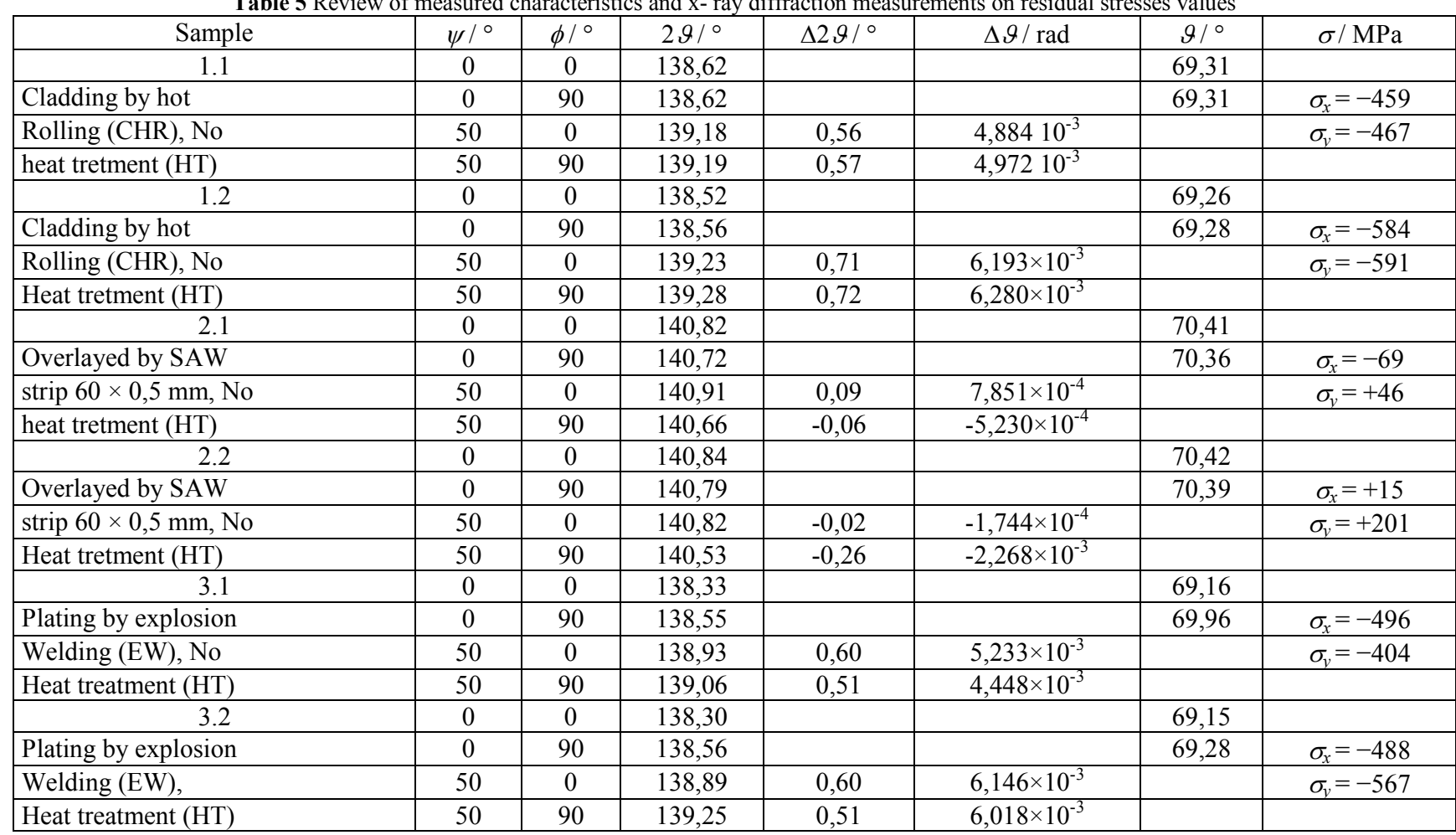

The position of top parabole is considered as a maximum interference line. After establishing angles at interference lines maximum (maximum impulse numbers), residual stresses normal to direction $(\phi, \psi)$ are $\sigma(\phi, \psi)=-\frac{E}{(1+v)} \cdot \frac{\operatorname{ctan} \vartheta}{\sin ^{2} \psi} \Delta \vartheta$ 


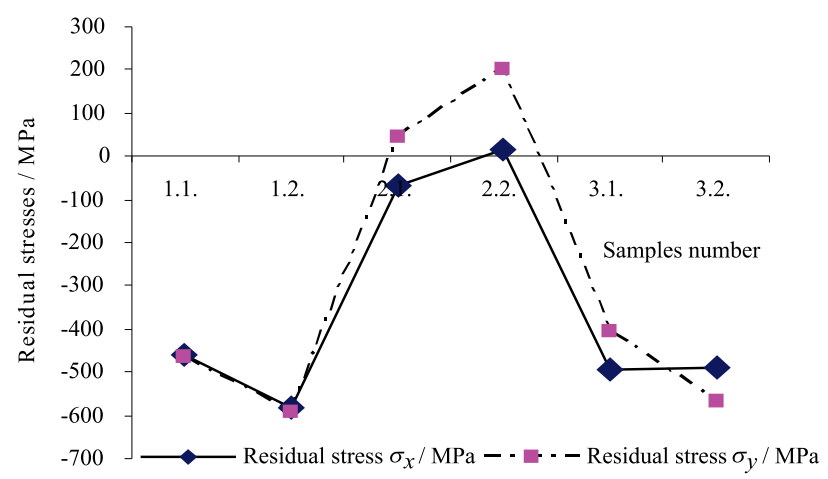

Figure 9 Graphic review of calculated residual stresses values $\sigma_{x}$ and $\sigma_{y}$ on sample plated by austenitic corosion resistant steel

Tab. 5 presents related values. Graphical presentation of calculated residual stresses on $(2 \vartheta)$ at maximal impulse number (interference lines maximum) is shown in Fig. 9.

\section{Conclusions}

In all applied cladding procedures with heat reatment by annealing a drop of residual stresses was determined. Type of plating procedure has a significant influence on the value of residual stresses.

Heat treatment has significant influence on range and nature of plating surface residual stresses, as present at specimens plated by submerged-arc welding (SAW) with strip electrodes in two beads. The transformation of compressed stresses into tensile stresses is very unfavourable if respecting the tendency of plating austenitic corrosion resistant steel to stress corrosion cracking. When PWHT is applied, base metal coarse grained areas and residual stresses changing into tensile have the tendency of potential intergranular underclad cracks.

\section{References}

[1] Macherauch, E. HTM Beiheft, Carl Hanser Verlag, Muenchen. 1985.

[2] Kobayashi, A., S. Handbook on experimental mechanics, SEM N.Y. USA, 1993.

[3] Dhooge, A.; Vinckier, A. Reheat cracking - a review of recent studies. // Int. J. Pres. Ves. \& Piping. 27, (1987), pp 239-269. DOI: 10.1016/0308-0161(87)90012-3

[4] Vinckier, A.; Jubin L.; Dhooge, A.; Bourges P. Study of the phenomenon of cracking during stress relief heat treatments in welded joints of quenched and tempered high-strength steels ISBN 92-827-6166 C ECSC-EC-EAEC, Brussels Luxembourg, 1996.

[5] Dally, W.; Riley, F. Experimental stress analysis, Int. Student Edit, Mc Graw-Hill Book Co., N.Y., 1987.

[6] Husnjak, M.; Kralj, S. Primjenjivost metoda mjerenja napetosti, International conference on residual stresses in welding joints, Zagreb, 1982., pp. 235-240.

[7] Noyan, I. C.; Cohen, J. B. Residual stress measurements by diffraction and interpretation, Verlag New York, 1987.

[8] Fitzpatrick, M. E.; Fry, A. T.; Holdway, P.; Kandil, F. A.; Shackleton, J.; Suominen, L. Determination of Residual Stresses by X-ray Diffraction - Issue 25 National Physical Laboratory Teddington, Middlesex, United Kingdom, TW11 0LW, http:// www.npl.co.uk/

[9] Grešovnik, F. Nastajanje i rentgensko mjerenje zaostalih naprezanja, International conference on modern methods of special steels reseaeching, Zagreb 1980, pp. 100-114.
[10] Hornbach, D. J.; Prevéy, P. S. Tensile residual stress fieldproduced in austenitic alloy weldments, Lambda Research Technologies http://www.lambdatechs.com/.

\section{Authors' addresses}

Branko Mateša, Assist. Prof. dr. sc.

Mechanical Engineering Faculty in Slavonski Brod Josip Juraj Strossmayer University of Osijek

Trg Ivane Brlić Mažuranić 2, 35000 Slavonski Brod, Croatia E-mail:bmatesa@gmail.com

Zoran Kožuh, Prof. dr. sc.

Faculty of Mechanical Engineering and Naval Arhitecture University of Zagreb

Ivana Lučića 5, 10000 Zagreb, Croatia

E-mail: zoran.kozuh@fsb.hr

Marko Dunđer, Prof. dr. sc.

Department of Polytechnics

University of Rijeka

Vukovarska 58, 51000 Rijeka, Croatia

E-mail: marko.dundjer@ffri.hr

Ivan Samardžić, Prof. dr. sc.

Mechanical Engineering Faculty in Slavonski Brod Josip Juraj Strossmayer University of Osijek

Trg Ivane Brlić Mažuranić 2, 35000 Slavonski Brod, Croatia

E-mail: ivan.samardzic@sfsb.hr 